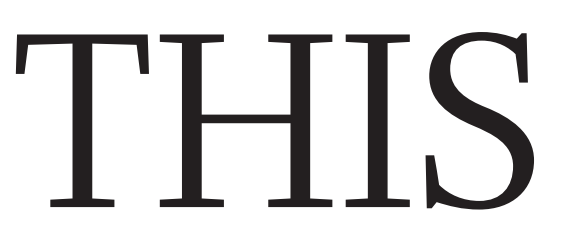

EDITORIALS
CLIMATE Political leaders aim for full phase-out of carbon emissions p.128

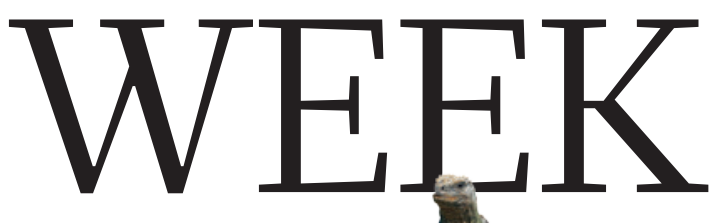

WORLD VIEW How funders can encourage data sharing $\mathbf{p . 1 2 9}$
EVOLUTION Galapagos genomes reveal secrets of marine iguana $\mathbf{p . 1 3 1}$

\title{
Sex and the law
}

\section{A report from South Africa on the science of human sexuality and its implications for policy-making brings African countries a step closer to confronting laws that criminalize homosexuality.}

$\mathrm{T}$ The motto of the Academy of Science of South Africa is: "Applying scientific thinking in the service of society." There are many types of scientific thinking, of course, and not all of them serve society particularly well. Scientific thinking on homosexuality, for instance, has a very chequered past.

Until the mid-1970s, the American Psychiatric Association listed homosexuality in its official manual of mental disorders. Academic journals at the time were filled with case reports of psychologists and medics trying to turn gay men straight. A new book, 'Curing Queers': Mental Nurses and Their Patients, $1935-74$ by Tommy Dickinson, details cases of such 'aversion therapy' from the United Kingdom, where behavioural psychologists tried to erase homosexual behaviour by associating it with unpleasant sensations, including pain.

Scientific thinking on homosexuality, and other issues of sex, sexuality and gender, has moved on considerably since then. Thankfully, so too have many societies. Last month, Ireland became the latest country to legalize same-sex marriage. Science played no part in that decision, and why should it have?

Unfortunately, not everyone sees it that way. Science - or, more accurately, a flawed version of scientific thinking - is still used as a cloak for prejudice and persecution of homosexuals in countries across Africa and elsewhere. In February last year, for example, the press office of the Ugandan presidential State House formally announced that President Yoweri Museveni was to sign an "anti-gay bill after experts prove there is no connection between biology and being gay".

The 'scientific' thinking here (and bear with us) is that, because researchers have not found a specific gene that is associated with homosexuality, science cannot say that some people are born gay. And if they are not born that way, the elastic logic goes, homosexuality is a lifestyle choice. And states are within their rights to criminalize some behaviour. "I want a scientific answer," the president said, "not a political answer."

As we report on page 135, a scientific answer on this question is now available. The Academy of Science of South Africa has published a comprehensive study on the science of human sexuality and the implications for policy (see go.nature.com/q3rr4k). The report demolishes the political lie that anti-gay laws are supported by scientific evidence. And it shows that, contrary to the public-health claims of politicians who want to criminalize homosexuality, such laws hamper efforts to combat the spread of HIV and other sexually transmitted infections.

What difference will this report make? It would be naive to expect that rational argument - scientific thinking - can draw the poison from the venomous attitudes that drive hatred and prejudice. But the report, if it is distributed widely, can still act as a useful tool for those who have the courage within Africa to oppose unjust laws.

As the report points out, there is precedent here. South Africa under the apartheid regime, and other places, tried to justify laws against mixed-race marriages with references to science and public health. The 'natural order' demanded that everyone stick to their own ethnic

and racial groups. Countering such claims alone does not dismantle the regime that produces them, but it offers ammunition to undermine claims to legitimacy that such regimes may make. Science helped to strip away the cloak to reveal the true, ugly motivations for such racial discrimination (and continues to do so, because the argument that 'mixed' couples produce more-dysfunctional families than non-mixed ones still

"The study could find no evidence that homosexuality is anything other than a feature on aspectrum of humansexuality." which has officially endorsed the findings.

Museveni has the scientific answer he requested. As a phrase used many times in the report reads, the study "could find no evidence that" homosexuality is anything other than a feature on a spectrum of human sexuality. Indeed, the more that scientific thinking is applied to human sex and gender issues, the clearer it becomes that the evidence points towards greater diversity as the norm, not a culturally determined number of select options.

Spread the word. Share the report and its findings. Its conclusions, to those who respect scientific evidence, may be unremarkable. But sometimes stating the obvious again and again until people start to listen can be the best way for scientific thinking to serve society.

\section{Undue burdens}

\section{Proposed controls on foreign operations in China are a threat to scientific collaboration.}

$\longrightarrow$ hina seems to be cracking down on everything at the moment. Its anti-corruption drive has government officials and businesses in all sectors shaking. The government has tightened its grip on the Internet, and the block on accessing Google and Google Scholar in China has hamstrung researchers' ability to keep abreast of the latest scientific trends. Some proposed restrictions are so vague that they could be applied to almost anything. What do government officials mean, for example, when they say that 'Western values' have no place in Chinese university textbooks?

There are many reasons for these moves. President Xi Jinping is still 
consolidating power, in a system rife with corruption. Meanwhile, an increasingly vocal populace complains of rich officials, environmental problems and food safety.

The government wants to stay in charge of efforts to deal with problems and maintain its goal of stability. It is not alone in such efforts. And it is not alone in setting its sights on what it sees as a possible source of dissent and social strife: non-governmental organizations (NGOs). Russia and India in recent months have already set out worrying plans to stifle such operations. Now China is following.

In China, domestic NGOs are, for the most part, governmentorganized bodies, and so are still under government influence. But foreign NGOs are a concern to the government, and a potential destabilizing force, especially when they try to spread 'Western values'.

Last year, the government surveyed foreign NGOs operating in China and counted about 1,000 permanent operations; when short-term projects are included, NGOs in China number up to 6,000. The government estimates that these groups pour hundreds of millions of dollars into some 20 areas, including health, environmental protection and education. To Chinese officials, these are alarmingly high numbers.

China feels that its grip on these organizations has been too loose. Accordingly, over the past month it has sought comments on a new draft law - the Non-Mainland Non-Governmental Organizations Management Law - that will tighten restrictions on NGOs.

The move may not be a surprise, given the political mood. But the proposed scope of the law is broader than many people expected, and is causing alarm. Its definition of an NGO is so broad - all activities of "not-for-profit, non-governmental social organizations" - that, according to Jia Xijin, a specialist on NGOs in China at Tsinghua University, it covers all organized activities between Chinese nationals and foreigners. Many people, citizens and visitors alike, probably have no idea that the law will apply to them.

The new rules would require individuals or institutions wishing to carry out activities in China to get a sponsor, such as a ministry or other agency of local government. Then they must apply for permission - not to the civil-affairs ministry, as in the existing system, but to the public-security bureau.

What will happen when the public-security bureaus, which are accustomed to operating with a police mindset, start sizing up applications for scientific collaborations? At the very least, the result would be undue, and potentially forbidding, restrictions and red tape. It would probably, for instance, discourage studies of environmental problems that regional governments are not ready to admit to. At the very worst, it would allow the persecution of institutions or of individuals from blacklisted institutions.

Could a political demonstration at a university overseas mean that researchers from that university would no longer be welcome

"Overseas
institutions
have already
expressed
concern."
in China? What if an individual had some other political connection that made officials uncomfortable?

The proposed law is not explicit in how it should be applied to specific collaborations or specific research projects. Those associated with universities or scientific societies in China fear that the decisions will be deferred to officials with little experience of science. What happens when these officials come across a project they do not fully understand? Will they want to take a chance on it? Most probably, observers fear, they would rather just reject it or, more likely, sit on it - and make things easy for themselves.

Overseas institutions have already expressed concern. One response to the Chinese consultation came from Harvard University in Cambridge, Massachusetts, which said that "universities should not be treated as non-governmental organizations and should not be subject to its provisions which, if implemented, could inadvertently make future transnational faculty and student collaborations more difficult, and therefore less frequent".

In an e-mail to Nature, a Harvard spokesperson put it diplomatically: "We would have concern with any law that might inhibit the future ability of faculty and students to work together on common areas of interest by creating new, undue burdens."

Jia says that second- or third-tier universities, and especially local or private universities, are likely to suffer. Whereas prominent governmentaffiliated universities such as Tsinghua or Peking universities, both in Beijing, would probably be accredited as authorized hosts for foreign NGOs that want to carry out temporary activities in China, smaller and less-well-connected universities are unlikely to get such approval.

Both science and China have benefited from the emphasis that the Chinese government has placed in recent years on research as a driver of growth and development. International links are a key component of that. To weaken such networks could do more than cut useful ties. It could undermine the stability that they help to bring.

\section{Tough targets}

\section{Concrete goals set out by the G7 nations lay the groundwork for a climate accord.}

\section{$\mathrm{T}$} he Group of 7 (G7) leading industrialized nations this week called for global greenhouse-gas emissions to be reduced by around $70 \%$ by 2050 , and for the world economy to be decarbonized by the end of the twenty-first century. These twin goals were issued in a communiqué at the conclusion of the group's meeting at Schloss Elmau in Krün, Germany, on 8 June, alongside a suite of promises to help developing nations to provide their citizens with clean energy, jobs, financial security and food.

To the credit of German Chancellor Angela Merkel, leader of the host nation, the commitments surpass all of the G7's previous promises. Most notably, the group has formally acknowledged - and quantified - the scale of the industrial renaissance that will be required to keep global average temperature increase to less than $2^{\circ} \mathrm{C}$ above pre-industrial levels. It has provided concrete and measurable targets that should help to make clear where precious capital and human resources should be invested - not just for other governments, but also for businesses. It should also make clear where resources should not be expended. The G7 nations renewed their pledge to end "inefficient" fossil-fuel subsidies.

The nations also reaffirmed a commitment, made in Copenhagen in 2009 , to increase climate aid for developing countries to US $\$ 100$ billion per year by 2020 , including both public and private financing. The communiqué calls for an expansion of renewable energy in developing countries, and further work to help the most vulnerable countries to prepare for climate change. In particular, the G7 pledged to ensure that 400 million people in developing nations have access to climate-risk insurance, to mitigate the effects of disasters such as droughts and storms.

The timing is good. Nations are wrapping up the latest round of climate talks in Bonn this week, with the aim of advancing a climate agreement to be signed in Paris later this year. Policy-makers have their work cut out if they are to sign a meaningful accord, and the G7 meeting represents a small step in the right direction.

But the world is still waiting for action that will give these targets credibility. Countries should adopt the G7 communiqués emissions targets and look for ways to expand climate-related investment in the developing world, where emissions are poised to rise quickly if no $\rightarrow$ NATURE.COM To comment online, click on Editorials at: go.nature.com/xhunqv intervention is made. The communique rightly points out that engagement by the private sector will be crucial to meeting these goals, but it is up to policy-makers to lay down the rules of the road. 